\title{
Combined Effects of Aerobic Exercise Training and Diacylglycerol Ingestion on Blood Lipid Profiles and Resting Metabolic Rate Changes in Obese Man
}

\author{
Moon-Youl Lee ${ }^{1}, \|-$ Young Paik $^{1}$ and Yi-Sub Kwak* \\ Department of Physical Education, Dong-Eui University, Busan 614-714, Korea \\ ${ }^{1}$ Department of Physical Education, Yonsei University, Seoul 120-749, Korea
}

Received July 10, 2010 /Accepted August 22, 2010

\begin{abstract}
The aim of this study was to investigate the combined effects of aerobic training and diacylglycerol ingestion on lipid profiles and resting metabolic rate changes in obese men. The subjects were divided into 3 groups: the Diacylglycerol group $(D, n=6)$, aerobic training group $(E, n=6)$, and diacylglycerol ingestion and aerobic training group $(\mathrm{DE}, \mathrm{n}=6)$. Diacylglycerol was ingested and aerobic exercise training performed for 12 weeks. The information received from the research was calculated through a Windows SPSS/PC+ Ver. 12.0K statistics package to standardize the means and deviations for each group. Then, two-way repeated measures ANOVA was used to evaluate the research hypothesis. Percent body fat, blood lipid profiles and resting metabolic rate changes were tested to evaluate the combined effect of aerobic exercise training and diacylglycerol ingestion. The results of this study were as follows; DG ingestion was shown to have a positive effect on body weight and body fat, while having a negative effect on resting metabolic rate changes. However, aerobic training was shown to have a positive effect on all factors including body weight, body fat, and resting metabolic rate. In conclusion, DG ingestion and exercise training were not shown to have synergistic effects on resting metabolic rate changes, percent body fat and lipid profiles, while aerobic exercise training was shown to have a positive effect on resting metabolic rate changes, percent body fat, and lipid profiles. To investigate the therapeutic effect of DG ingestion and aerobic exercise for obese men, analysis of catecholamine, cAMP, HSL, or insulin sensitivity should be considered.
\end{abstract}

Key words : Obesity, diacylglycerol (DG), aerobic training, resting metabolic rate (RMR)

\section{서 론}

비만은 현대인의 성인병 중 심각한 질병 중 하나로 신체건 강과 정신건강에 나쁜 영향을 미친다. 비만은 당뇨병, 관상동 맥 경화증, 고혈압, 관절질환 등을 유발시키며, 아울러 심리적 침체 및 소외 등의 원인이 되기도 한다[14]. 비만은 혈관 손상 (vascular damage)질환 이라고도 생각할 수 있으며, 이차적으 로 동맥경화가 촉진되어 관상동맥질환, 뇌경색, 말초혈관질환 등의 합병증을 일으키는 원인이 된다. 한편, 체중은 여러 가지 요소로 구성되어 있으며, 이 요소들의 상대적 무게는 서로 다 르게 구성되어 있다. 신체 전체 무게는 뼈, 근육, 지방, 혈액, 그리고 내장 등의 무게에 의해 이루어지고, 또 이 신체의 무게 는 제지방(lean body mass)과 체지방(fat mass)으로 나뉘어진 다. 제지방은 지방을 제외한 신체의 다른 모든 부분의 무게를 말한다. 반면에 지방은 주로 지세포라고 해서 각 기관을 싸고 있거나 피부의 바로 밑층에 저장되어 있고 신체의 각 기관 즉, 심장, 간, 폐, 뇌 등에도 분포되어 있다. 이러한 지방은 에너 지원과 내장의 보호 역할 및 신경과 세포막의 구성요소이며,

*Corresponding author

Tel : +82-51-890-1546, Fax : +82-51-890-2643

E-mail : ysk2003@deu.ac.kr
또한 열 손실을 막아 주는 보호막 역할을 한다[9]. 현재 비만을 가져오는 요소에 대해 과학자들은 에너지 대사의 불균형, 유 전적, 환경적 요인들을 포함한 다양한 이론을 지지하고 있다 [22]. 비만도를 낮추기 위한 방법에는 식이요법과 운동요법, 행동수정요법 그리고 약물요법 등이 이용되고 있다[2]. 최근에 는 체지방을 감소시키기 위해 anti-obesity agent라고 알려진 diacylglycerol (DG) 섭취 방법을 사용하고 있다[16]. 비만인들 은 체내 체지방이 과다 축적되고 섭취하는 전체 칼로리의 $30 \%$ 를 기름이 차지하고 있으므로[1] anti-obesity 특징을 가진 식 이성 지방을 섭취하여 체내 체지방을 감소시킬 수 있다. 선행 연구에 따르면 여성 12 명을 대상으로 단기간 DG $(65 \% \sim 70 \%$ 1,3-DG) oil을 투여한 결과 $\beta$-산화(B-oxidation)의 증가를 보였 을 뿐만 아니라[7] DG섭취는 비만 남성에게서도 비슷한 결과 를 가져 왔는데 이것은 과체중 남성에게 4 개월간 DG ( $~ 55 \%$ $1,3-\mathrm{DG}, 10 \mathrm{~g} / \mathrm{d})$ 와 TG oil을 투여했을 때, DG와 TG를 섭취한 피험자에서 각각 체중의 $2.6 \mathrm{~kg}$ 과 $1.1 \mathrm{~kg}$ 의 감소를 보고하였다 [12]. 또한, 혈청 지질 성분에 관한 연구에서는 3 개월간 $9.8 \mathrm{~g}$ 의 $\mathrm{DG}(70 \%$ 1,3-DG) 섭취 후 초저밀도 지단백(very low-density lipoprotein; VLDL)과 혈청지단백(lipoprotein)이 감소하였으 며, 고밀도 지단백(high-density lipoprotein; HDL)은 중성지 방(Triglycerides; TGs)이나 총 콜레스테롤 농도의 변화 없이 
증가되었고 또한, 내장지방이 감소하였다는 연구결과도 보고 하였다[19]. 그러나 가장 효과적으로 체지방을 감소시키기 위 해서는 식이요법만이 아닌 신체활동을 통해 칼로리를 소모시 키면서 근육을 발달시키는 운동요법과 식이요법의 병행이 가 장 이상적이라고 알려져 있다. 지방이 주 에너지원으로 이용 되는 지구력 운동 시 지방량이 감소함에 따라 제지방량이 증 가되고[21], 그 결과 안정 시 대사량이 증가한다고 알려져 있다 [15]. 안정 시 대사량이란 완전히 안정된 상태에서 요구되는 에너지 소비량으로 정의할 수 있으며, 비만 정도가 심한 사람 의 경우, 정상인들에 비해 안정 시 대사량이 약 $500 \mathrm{kcal}$ 정도 더 높게 나타나지만, 체중 감량 시 안정 시 대사량은 15 20\% 정도 낮아진다[17]. 이러한 안정 시 대사량은 제지방량과 밀접 한 관련이 있다고 알려져 있으며 높은 강도의 운동 시 대사량 이 증가되며, 훈련을 통해 근육량이 증가되면 에너지 소비를 높여 안정 시 대사량을 증가시킨다는 선행 연구 결과들이 있 다[10]. 그러나 이제까지 비만인들을 대상으로 한 연구들은 운 동요법, 식이요법, 혹은 운동과 식이요법에 따른 체지방 감소 효과에 관한 연구가 대부분이었다. 하지만 비만인에게 DG 섭 취와 유산소운동의 병행이 제지방량의 증가와 더불어 안정 시 대사량의 증가를 도모하고 지질성분을 변화 시킨다면 건강 증진은 물론 대사적 질환을 예방 할 수 있을 것을 기대해 연구 의 필요성이 요구 되어진다.

따라서, 본 연구는 체지방을 감소시키는데 효과적이라는 diacylglycerol (DG) 섭취와 유산소운동이 체구성비의 변화 및 혈중 지질 개선에 미치는 영향을 규명하고 안정 시 대사량 변화를 관찰함으로써 임상적 및 대사적 측면에서 비만 개선 효과를 규명하는데 그 목적이 있다.

\section{재료 및 방법}

\section{연구대상}

본 연구는 비만인을 대상으로 12 주 동안의 diacylglycerol (DG) 섭취와 유산소 트레이닝 후 체중, 체지방, RMR, 혈중 지질성분에 미치는 영향을 규명하는데 그 목적이 있고, 본 연 구의 대상은 의학적으로 다른 질병을 동반하지 않은 비만 남 자 대학생으로서 연구의 의의를 충분히 이해하고 자발적으로 참여 의사를 밝힌 사람으로 선정하였으며, 체지방 측정 후 $25 \%$ 미만인 자와 흡연자는 대상에서 제외하였다. 피험자의 선 택 시 Physical Activity Readiness Questionnaire (PAR-Q)를 실시하여 비만 이외 고혈압, 심장기능 이상 등과 같은 질병이 있었는지 확인하였고, 연령, 체구성비, 그리고 체력 등 장시간 운동수행과 밀접한 관련이 있는 변인들에 대한 오차를 최소화 하기 위해서 사전 테스트를 거쳐 최종적으로 18 명을 선발하였 다. 모든 피험자들은 기본검사와 사전검사가 끝난 후 세가지 집단에 6명씩 무선 배정하였다. 첫 번째 실험군(D)은 diacylglycerol 섭취 조건으로 12주 동안 diacylglycerol을 섭취하
였고, 두 번째 실험군(E)은 12 주 동안 러닝(유산소) 트레이닝을 실시하였다. 그리고 마지막 세 번째 실험군 $(\mathrm{DE})$ 은 12 주 동안 diacylglycerol 섭취와 유산소 트레이닝을 실시하였으며 본 실 험에 참가한 피험자의 신체적 특성은 Table 1 과 같다.

\section{훈련 방법}

12 주 동안의 유산소 트레이닝은 주 3회 달리기 프로그램을 실시하였다. 운동 시간은 준비운동(10분), 본 운동( 40 분), 정리 운동(10분)을 포함하여 총 60 분으로 하였고, $\mathrm{ACSM}$ 의 Training Progression for the Sedentary Low-Risk Participants 를 참고로 트레이닝 강도를 산출하였으며, 트레이닝 강도는 0 2주는 $50 \% \mathrm{VO}_{2} \max , 3 \sim 10$ 주는 $65 \sim 70 \% \mathrm{VO}_{2} \max , 11 \sim 12$ 주는 $70 \% \mathrm{VO}_{2} \max$ 로 설정하였다[2]. 훈련 시 정확한 트레이닝 강도로 운동을 실시할 수 있도록 Karvonen's Fomular를 참고 하여 트레이닝 강도에 맞는 심박수를 산출하였고, 트레이닝 중 심박수 확인을 위하여 polar를 착용하고 훈련하였다.

\section{2주 diacylglycerol (DG) 섭취 방법 및 시기}

모든 피험자들은 기본검사와 사전검사 후 세 가지 서로 다 른 실험 조건 $(\mathrm{D}, \mathrm{E}, \mathrm{DE})$ 에 참여하였다. Diacylglycerol 섭취는 두 그룹 $(\mathrm{D}, \mathrm{DE})$ 에서 실시하였고, 두그룹 피험자들에게 제공되 는 diacylglycerol의 양은 동일하였다. Diacylglycerol은 Kao社. (Japan)의 Healthy Econa Cooking oil을 사용하였고, 일본 후 생성의 “특수목적 건강식품(FOSHU, Foods for Specified Health Use)"으로 승인된 oil로써, DG 함유량은 약 $80 \mathrm{~g}$ $\mathrm{DG} / 100 \mathrm{~g}$ 이며 DG 구성은 Table 2와 같다. 투여는 12주 동안 실시하였고, 1 일 $10 \mathrm{~g}$ 을 섭취하는데 단독 또는 평상 식이에 첨가하여 함께 섭취하도록 하였다.

\section{측정 방법}

모든 피험자들은 기본검사로 신장, 체중, 체지방률 $(\%$ body fat)을 사전검사 1 주일 전에 측정하였다. 신장과 체중은 자동

Table 1. Physical characteristics of subjects

\begin{tabular}{lccc}
\hline Group & $\mathrm{D}(\mathrm{n}=6)$ & $\mathrm{E}(\mathrm{n}=6)$ & $\mathrm{DE}(\mathrm{n}=6)$ \\
\hline Age $(\mathrm{yr})$. & $26.8 \pm 4.0$ & $22.3 \pm 4.0$ & $22.0 \pm 3.0$ \\
Height $(\mathrm{cm})$ & $178.0 \pm 3.0$ & $175.7 \pm 3.6$ & $174.2 \pm 4.6$ \\
Weight $(\mathrm{kg})$ & $102.28 \pm 12.32$ & $86.11 \pm 11.00$ & $92.36 \pm 13.52$ \\
body fat $(\%)$ & $29.08 \pm 2.67$ & $25.81 \pm 1.09$ & $27.88 \pm 2.61$ \\
\hline
\end{tabular}

Table 2. Diacylglycerol oil composition and contents

\begin{tabular}{lc}
\hline Ingredient & Ratio (\%) \\
\hline Acylglycerol Species(wt\%) & \\
Triacylglycerol & 16 \\
Diacylglycerol & 84 \\
(1, 3-Diacylglycerol) & $(58)$ \\
(1, 2-Diacylglycerol) & $(26)$ \\
\hline
\end{tabular}


신체 계측기(Fanics, FE810)를 이용하여 측정하였고, 체구성비 의 측정은 전기 저항법에 의해서 측정되는 Biodynamics 社 (U.S.A) Model 310의 Body Composition Analyzer를 이용하 여 체지방률 $(\%)$ 을 측정하였다.

\section{$\mathrm{RMR}$ (안정 시 대사량)}

안정 시 대사량(Resting Metabolic Rate: RMR)의 측정은 신빙성 있는 값을 얻기 위해 최소한 12 시간의 공복을 유지할 수 있도록 하고, 다음날 아침 6시에 움직임이 최소한으로 자제 된 상태에서 Cortex Biophsik Gm (KOREA)의 Meta Max 3B 를 이용하여 측정하였다. 피험자들의 안정 시 대사량, 호흡상 $(\mathrm{RQ})$ 과 그 밖의 가스분석 자료들은 Cortex Biophsik Gm (KOREA)의 Meta Max 3B를 통해 매 15초마다 자동으로 측정 되었다. 본 실험에 있어서 안정 시 대사량은 45 분간 측정하였 으며, 상황에 따라서는 45 분 이상을 측정하였다.

\section{혈중 지질성분}

혈액 채취는 모든 그룹 $(\mathrm{D}, \mathrm{E}, \mathrm{DE})$ 에서 0 주 그리고 12 주의 안정 시와 운동 종료 후 실시하였다. 채취는 polar를 이용하여 심박수를 측정하여 안정 시 심박수에 도달하면 안정 시 채혈 을 하였다. 채혈은 임상 병리사에 의해 각 시기마다 $10 \mathrm{ml}$ 진공 채혈관(vaccum tube)과 22 gage needle을 이용하여 전완정맥 (antecubital vein)에서 채취하였고 피험자의 전완정맥에서 채 취한 혈액으로 혈청 지질성분을 측정하기 위하여 총콜레스테 롤(TC), 고밀도지단백콜레스테롤(HDL), 저밀도지단백콜레스 테롤(LDL) 및 중성지방(TG)을 분석하였다. 총 콜레스테롤은 일 본 Hitachi 747을 이용하여 Enzymatic colorimetry원리를 이용 한 자동분석법을 이용하였고, 독일 Boehringer Mannheim社의 Total- cholesterol 시약을 사용하였다. 고밀도지단백콜레스테 롤(HDL)은 일본 Hitachi 7150을 이용하여 Enzymatic colorimetry원리를 이용한 자동분석법을 이용하였고, 역시 독일 Boehringer Mannheim社의 HDL-Cholesterol 시약을 사용하 였으며, 저밀도지단백콜레스테롤(LDL)은 일본 Hitachi 7150 을 이용하여 자동분석법으로 측정하였고, 일본 Daichi社의 LDL-Cholesterol 시약을 사용하였다. 중성지방은 일본 Hitachi 747을 이용하여 효소적 비 소거법을 사용하였고, 독일 Boehringer Mannheim社의 Triglyceride 시약을 사용하여 자 동분석법으로 분석하였다.

\section{자료 처리 방법}

본 연구에서 얻은 자료의 분석은 SPSS/PC+ Ver. 12.0 통계 패키지를 적용하여 연구 가설을 검증하였고 본 연구에서 얻어 진 모든 그룹 간, 사전 · 사후 실험 및 채혈시점에 대한 종속 변인들의 평균(M)과 표준편차(SD)를 구하였다. $\mathrm{DG}$ 투여와 12 주간 유산소 운동 그룹 $(\mathrm{D}, \mathrm{E}, \mathrm{DE})$ 의 사전 - 사후 실험 시 채혈 시점에 따라 혈중 지질성분 및 RMR 변화에 미치는 영향을
알아보기 위하여 이원분산분석(two-way ANOVA)을 실시하 였고 주 효과가 유의한 결과에 대해서는 Tukey의 사후검증법 을 이용하였으며, 통계적 유의수준은 .05로 하였다.

\section{결 과}

우선 각 그릅 체지방의 변화는 Fig. 1 에 나타나 있다. 모든 그룹에서 12 주 동안의 그룹별 처치가 진행됨에 따라 체지방이 감소하는 경향을 보였다. 우선 그룹별 처치시기를 기준으로 0 주 와 12 주 사이에서 $1.51 \%$ 로 가장 큰 차이를 보였으며, 0 주와 6 주, 6 주와 12 주 사이에서도 각각 $0.71 \%$ 와 $0.8 \%$ 로 차이가 나타났으 나 통계적인 유의성은 보이지 않았다(p>0.005). 그룹 간의 변화 를 살펴보면, $\mathrm{D}$ 그룹과 $\mathrm{E}$ 그룹에서 가장 큰 그룹 차 $3.9 \%$ 를 기록 하였고, 처치 전 체지방이 많은 순서로는 $\mathrm{D}, \mathrm{DE}, \mathrm{E}$ 그룹의 순서 로 나타났다. $\mathrm{D}$ 그룹에서는 0주 $29.08 \pm 2.67 \%, 6$ 주 $28.41 \pm 2.59 \%$, 12 주 $27.53 \pm 2.47 \%$ 로 감소하는 경향을 보였고 통계적으로 유의 한 차이는 나타나지 않았으나, 0 주에서 6 주는 $0.67 \%$ 감소하였 고 6 주에서 12 주는 $0.88 \%$ 감소하는 경향을 보였다. 또한 0 주에 서 12 주는 $1.55 \%$ 감소하였고 백분위 $5.3 \%$ 감소하는 경향을 보였으나, 통계적으로 유의한 차이는 나타나지 않았다. E그룹 에서는 0 주 $25.81 \pm 1.09 \%, 6$ 주 $25.06 \pm 1.23 \%$, 12 주 $23.63 \pm 1.16 \%$ 로 감소하는 경향을 보였고 통계적으로 유의한 차이는 나타나 지 않았으나, 0 주에서 6 주는 $0.75 \%$ 감소하였고 6 주에서 12 주 는 $1.43 \%$ 감소하는 경향을 보였다. 또한 0 주에서 12 주는 $2.18 \%$ 감소하였고 백분위 $8.4 \%$ 감소하는 경향을 보였으나, 통계적으 로 유의한 차이는 나타나지 않았다. $\mathrm{DE}$ 그룹에서는 0 주 $27.88 \pm 2.61 \%, 6$ 주 $27.05 \pm 3.12 \%, 12$ 주 $25.66 \pm 4.14 \%$ 로 감소하는 경향을 보였고 통계적으로 유의한 차이는 나타나지 않았으나, 0 주에서 6 주는 $0.83 \%$ 감소하였고 6 주에서 12 주는 $1.39 \%$ 감소 하는 경향을 보였다. 또한 0 주에서 12 주는 $2.22 \%$ 감소하였고 백분위 $8 \%$ 감소하는 경향을 보였으나, 통계적으로 유의한 차 이는 나타나지 않았다.

각 그룹 안정 시 대사량의 변화는 Fig. 2에 나타나 있다. $\mathrm{D}$ 그룹을 제외하고 모든 그룹에서 증가하는 경향을 보였으며,

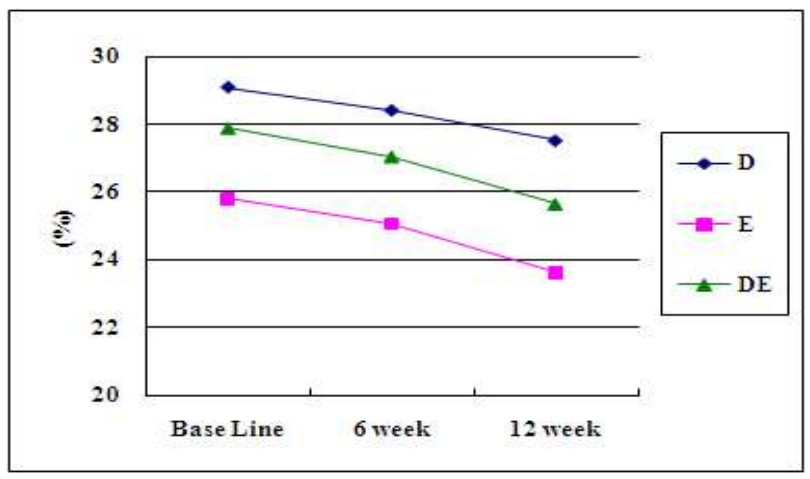

Fig. 1. The change of body fat after 12 weeks treatment. 




Fig. 2. The change of resting metabolic rate after 12 weeks treatment.

안정 시 대사량에 대한 그룹 및 시기에 따른 변화를 관찰하기 위하여 Two-way ANOVA를 실시하였다. 우선 그룹별 처치시 기를 기준으로 0 주와 12 주 사이에서 $66.7 \mathrm{kcal}$ 로 가장 큰 차이 를 보였으며, 0 주와 6 주, 6 주와 12 주 사이에서도 각각 $56.3 \mathrm{kcal}$ 와 $10.4 \mathrm{kcal}$ 로 차이가 나타났다 $(\mathrm{p}>0.05)$. 그룹 간 비교에서는 $\mathrm{D}$ 그룹을 제외하고 모든 그룹에서 증가하는 경향을 보였으나, 통계적으로 유의한 차이는 나타나지 않았다. $\mathrm{D}$ 그룹에서는 0 주 $1824 \pm 11 \mathrm{kcal} / \mathrm{d}, 6$ 주 $1808 \pm 90 \mathrm{kcal} / \mathrm{d}, 12$ 주 $1766 \pm 10 \mathrm{kcal} / \mathrm{d}$ 로 감소하는 경향을 보였고 통계적으로 유의한 차이는 나타나 지 않았으나, 0 주에서 6 주는 $0.9 \%$ 감소하였고 6 주에서 12 주는 $2.3 \%$ 감소하는 경향을 보였다. 또한 0 주에서 12 주는 $58 \mathrm{kcal} / \mathrm{d}$ 감소하였고 $3.2 \%$ 감소하는 경향을 보였지만 통계적으로 유의 한 차이는 나타나지 않았다. E그룹에서는 0주 $1642 \pm 11 \mathrm{kcal} / \mathrm{d}$, 6 주 $1734 \pm 77 \mathrm{kcal} / \mathrm{d}, 12$ 주 $1738 \pm 89 \mathrm{kcal} / \mathrm{d}$ 로 증가하는 경향을 보였고 통계적으로 유의한 차이는 나타나지 않았으나, 0 주에 서 6 주는 $5.6 \%$ 증가하였고 6 주에서 12 주는 $0.2 \%$ 증가하는 경 향을 보였다. 또한 0 주에서 12 주는 $96 \mathrm{kcal} / \mathrm{d}$ 증가하였고 $5.8 \%$ 증가하는 경향을 보였지만 통계적으로 유의한 차이는 나타나 지 않았다. DE그룹에서는 0주 $1677 \pm 16 \mathrm{kcal} / \mathrm{d}$, 6주 $1727 \pm 14$ $\mathrm{kcal} / \mathrm{d}, 12$ 주 $1756 \pm 15 \mathrm{kcal} / \mathrm{d}$ 로 증가하는 경향을 보였고 통계 적으로 유의한 차이는 나타나지 않았으나, 0 주에서 6 주는 3\% 증가하였고 6 주에서 12 주는 $1.7 \%$ 증가하는 경향을 보였다.

혈중 TC의 변화는 Fig. 3에 나타나 있다. 혈중 $\mathrm{TC}$ 는 모든 그룹에서 12 주 처치 후 감소하는 경향을 보였다. TC에 대한 그룹 및 시기에 따른 변화를 관찰하기 위하여 Two-way ANOVA를 실시하였다. 그룹 간의 변화를 살펴보면, 12 주 처 치 후 $\mathrm{TC}$ 가 높은 순서로는 $\mathrm{DE}, \mathrm{D}, \mathrm{E}$ 그룹의 순서로 나타났다. 결과에서 처치 시기 및 그룹 간 비교에서는 모든 그룹에서 감소하는 경향을 보였으나, 통계적으로 유의한 차이가 나타나 지 않았다. 안정 시 $\mathrm{D}$ 그룹에서는 0주 $183.67 \pm 47.84 \mathrm{mg} / \mathrm{dl}, 12$ 주 $174.16 \pm 35.60 \mathrm{mg} / \mathrm{dl}$ 로 $5.2 \%(9.51 \mathrm{mg} / \mathrm{dl})$ 감소하는 경향을 보였으나, 통계적으로 유의한 차이는 나타나지 않았다. E그룹 에서는 0주 $152.16 \pm 21.91 \mathrm{mg} / \mathrm{dl}, 12$ 주 $140.83 \pm 22.63 \mathrm{mg} / \mathrm{dl}$ 로 $7.4 \%(11.33 \mathrm{mg} / \mathrm{dl})$ 감소하는 경향을 보였으나, 통계적으로

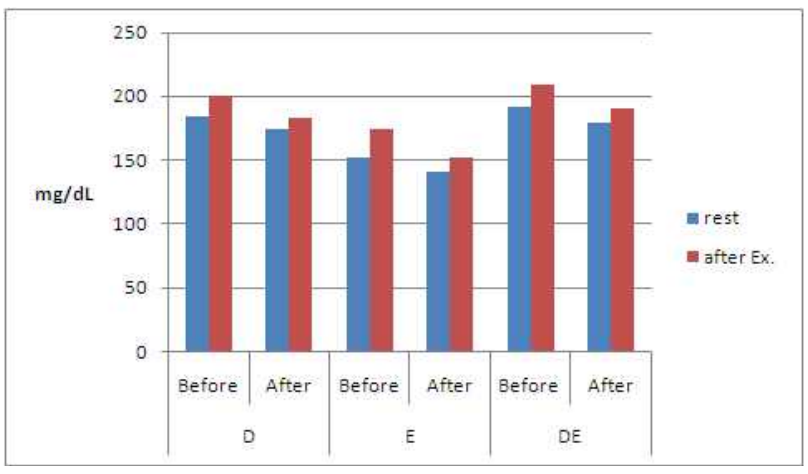

Fig. 3. The change of plasma TC concentration after 12 weeks treatment.

유의한 차이는 나타나지 않았다. 또한 처치 전 다른 그룹과의 비교에서 가장 낮은 수치를 보였다. $\mathrm{DE}$ 그룹에서는 0 주 $192.16 \pm 32.57 \mathrm{mg} / \mathrm{dl}, 12$ 주 $179.83 \pm 30.78 \mathrm{mg} / \mathrm{dl}$ 로 $6.4 \%$ (12.33 $\mathrm{mg} / \mathrm{dl}$ )감소하는 경향을 보였으나, 통계적으로 유의한 차이는 나타나지 않았다. 유산소 운동 후 $\mathrm{D}$ 그룹에서는 0 주 $200.66 \pm 49.38 \mathrm{mg} / \mathrm{dl}, 12$ 주 $183.00 \pm 39.45 \mathrm{mg} / \mathrm{dl}$ 로 $8.8 \%$ (17.66 $\mathrm{mg} / \mathrm{dl}$ 감소하는 경향을 보였으나, 통계적으로 유의한 차이는 나타나지 않았다. E그룹에서는 0 주 $174.66 \pm 30.53 \mathrm{mg} / \mathrm{dl}, 12$ 주 $152.16 \pm 30.01 \mathrm{mg} / \mathrm{dl}$ 로 $12.9 \%(22.5 \mathrm{mg} / \mathrm{dl})$ 감소하는 경향을 보였으나, 통계적으로 유의한 차이는 나타나지 않았다. 또한 처치 전 다른 그룹과의 비교에서 가장 낮은 수치를 보였다. $\mathrm{DE}$ 그룹에서는 0주 $208.83 \pm 35.45 \mathrm{mg} / \mathrm{dl}, 12$ 주 $190.83 \pm 24.79$ $\mathrm{mg} / \mathrm{dl}$ 로 $8.6 \%(18 \mathrm{mg} / \mathrm{dl})$ 감소하는 경향을 보였으나, 통계적 으로 유의한 차이는 나타나지 않았다. 또한 처치 후 다른 그룹 과의 비교에서 가장 높은 수치를 보였다.

혈중 Triglyceride (TG) 농도 변화는 Fig. 4 에 나타나 있다. 혈중 $\mathrm{TG}$ 는 모든 그룹에서 12 주 처치 후 감소하는 경향을 보였 다. TG에 대한 그룹 및 시기에 따른 변화를 관찰하기 위하여 Two-way ANOVA를 실시하였다. 그룹 간의 변화를 살펴보 면, 처치 후 안정 시 $\mathrm{TG}$ 가 낮은 순서로는 $\mathrm{E}, \mathrm{D}, \mathrm{DE}$ 그룹의 순서로 나타났고 처치 시기 및 그룹 간 비교에서는 통계적으

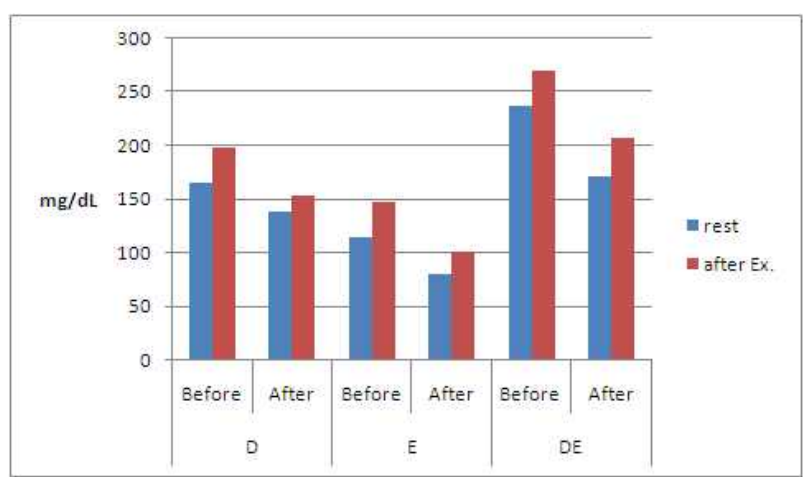

Fig. 4. The change of plasma TG concentration after 12 weeks treatment. 
로 유의한 차이가 나타나지 않았다. 안정 시 $\mathrm{D}$ 그룹에서는 0 주 $165.33 \pm 71.16 \mathrm{mg} / \mathrm{dl}, 12$ 주 $138.83 \pm 58.59 \mathrm{mg} / \mathrm{dl}$ 로 $16 \%$ (26.5 $\mathrm{mg} / \mathrm{dl}$ ) 감소하는 경향을 보였으나, 통계적으로 유의한 차이 는 나타나지 않았다. E그룹에서는 0주 $114.16 \pm 64.02 \mathrm{mg} / \mathrm{dl}$, 12 주 $79.83 \pm 32.44 \mathrm{mg} / \mathrm{dl}$ 로 $30.1 \%(34.33 \mathrm{mg} / \mathrm{dl})$ 감소하는 경 향을 보였으나, 통계적으로 유의한 차이는 나타나지 않았다. $\mathrm{DE}$ 그룹에서는 0 주 $237.00 \pm 93.00 \mathrm{mg} / \mathrm{dl}, 12$ 주 $171.00 \pm 66.10$ $\mathrm{mg} / \mathrm{dl}$ 로 $27.8 \%(66 \mathrm{mg} / \mathrm{dl})$ 감소하는 경향을 보였으나, 통계 적으로 유의한 차이는 나타나지 않았다. 또한 처지 전 · 후 다 른 그룹과의 비교에서 가장 높은 수치를 보였다. 유산소 운동 후 $\mathrm{D}$ 그룹에서는 0 주 $198.16 \pm 75.60 \mathrm{mg} / \mathrm{dl}, 12$ 주 $153.16 \pm 57.83$ $\mathrm{mg} / \mathrm{dl}$ 로 $22.7 \%(45 \mathrm{mg} / \mathrm{dl})$ 감소하는 경향을 보였으나, 통계 적으로 유의한 차이는 나타나지 않았다. $\mathrm{E}$ 그룹에서는 0 주 $147.00 \pm 71.41 \mathrm{mg} / \mathrm{dl}, 12$ 주 $100.33 \pm 31.86 \mathrm{mg} / \mathrm{dl}$ 로 $31.7 \%$ (46.67 $\mathrm{mg} / \mathrm{dl}$ ) 감소하는 경향을 보였으나, 통계적으로 유의한 차이 는 나타나지 않았다. DE그룹에서는 0주 $270.00 \pm 109.79 \mathrm{mg} / \mathrm{dl}$, 12 주 $206.66 \pm 82.08 \mathrm{mg} / \mathrm{dl}$ 로 $23.5 \%(63.34 \mathrm{mg} / \mathrm{dl})$ 감소하는 경 향을 보였으나, 통계적으로 유의한 차이는 나타나지 않았다. 또한 처치 전·후 다른 그룹과의 비교에서 가장 높은 수치를 보였다.

혈중 LDL 농도 변화는 Fig. 5 에 나타나 있다. 혈중 LDL은 모든 그룹에서 12 주 처치 후 LDL이 감소하는 경향을 보였다. $\mathrm{LDL}$ 에 대한 그룹 및 시기에 따른 변화를 관찰하기 위하여 Two-way ANOVA를 실시하였다. 그룹 간의 변화를 살펴보 면, 처치 후 안정 시 $\mathrm{LDL}$ 이 낮은 순서로는 $\mathrm{E}, \mathrm{D}, \mathrm{DE}$ 그룹의 순서로 나타났다. 각 그룹별 처치에 따른 효과를 알아보기 위 한 One-way Repeated Measurement of ANOVA 결과에서 처치 시기 및 그룹간 비교에서는 통계적으로 유의한 차이가 나타나지 않았다. 안정 시 에서는 0 주 $117.33 \pm 39.84 \mathrm{mg} / \mathrm{dl}$, 12 주 $103.33 \pm 38.93 \mathrm{mg} / \mathrm{dl}$ 로 $11.9 \%$ (14 mg/dl) 감소하는 경향 을 보였으나, 통계적으로 유의한 차이는 나타나지 않았다. E그 룹에서는 0주 $96.50 \pm 19.08 \mathrm{mg} / \mathrm{dl}, 12$ 주 $84.50 \pm 18.94 \mathrm{mg} / \mathrm{dl}$ 로 $12.4 \%(12 \mathrm{mg} / \mathrm{dl})$ 감소하는 경향을 보였으나, 통계적으로 유 의한 차이는 나타나지 않았다. 또한 처치 전 다른 그룹과의

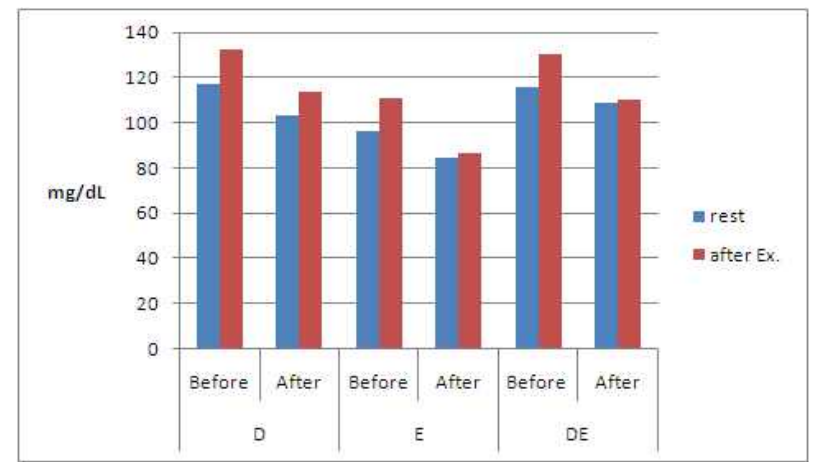

Fig. 5. The change of plasma LDL concentration after 12 weeks treatment.
비교에서 가장 낮은 수치를 보였다. DE그룹에서는 0주 116.00 $\pm 29.54 \mathrm{mg} / \mathrm{dl}, 12$ 주 $108.83 \pm 31.45 \mathrm{mg} / \mathrm{dl}$ 로 $6.2 \%(7.17 \mathrm{mg} / \mathrm{dl})$ 감소하는 경향을 보였으나, 통계적으로 유의한 차이는 나타나 지 않았다. 또한 처치 후 다른 그룹과의 비교에서 가장 높은 수치를 보였다. 안정 시 $\mathrm{D}$ 그룹에서는 0 주 $132.50 \pm 44.68$ $\mathrm{mg} / \mathrm{dl}, 12$ 주 $113.50 \pm 39.54 \mathrm{mg} / \mathrm{dl}$ 로 $14.3 \%$ (19 mg/dl) 감소하 는 경향을 보였으나, 통계적으로 유의한 차이는 나타나지 않 았다. 또한 처치 후 다른 그룹과의 비교에서 가장 높은 수치를 보였다. 유산소 운동 후 E그룹에서는 0 주 $110.83 \pm 20.31 \mathrm{mg} / \mathrm{dl}$, 12 주 $86.83 \pm 19.67 \mathrm{mg} / \mathrm{dl}$ 로 $21.7 \%(24 \mathrm{mg} / \mathrm{dl})$ 감소하는 경향을 보였으나, 통계적으로 유의한 차이는 나타나지 않았다. $\mathrm{DE}$ 그 룹에서는 0 주 $130.33 \pm 31.55 \mathrm{mg} / \mathrm{dl}, 12$ 주 $110.16 \pm 34.62 \mathrm{mg} / \mathrm{dl}$ 로 $15.5 \%(20.17 \mathrm{mg} / \mathrm{dl})$ 감소하는 경향을 보였으나, 통계적으 로 유의한 차이는 나타나지 않았다.

혈중 $\mathrm{HDL}$ 농도 변화는 Fig. 6 에 나타나 있다. 혈중 $\mathrm{HDL}$ 은 모든 그룹에서 증가하는 경향을 보였다. HDL에 대한 그룹 및 시기에 따른 변화를 관찰하기 위하여 Two-way ANOVA를 실시하였다. 그룹 간의 변화를 살펴보면, 처치 후 안정 시 $\mathrm{HDL}$ 이 높은 순서로는 $\mathrm{DE}$ 그룹, $\mathrm{E}$ 그룹, $\mathrm{D}$ 그룹의 순서로 나타났다. 안정 시 $\mathrm{D}$ 그룹에서는 0 주 $38.66 \pm 5.27 \mathrm{mg} / \mathrm{dl}, 12$ 주 $43.50 \pm 4.46$ $\mathrm{mg} / \mathrm{dl}$ 로 $12.5 \%(4.84 \mathrm{mg} / \mathrm{dl})$ 증가하는 경향을 보였으나, 통계 적으로 유의한 차이는 나타나지 않았다. 또한 처치 후 다른 그룹과의 비교에서 가장 낮은 수치를 보였다. $\mathrm{E}$ 그룹에서는 0 주 $38.50 \pm 3.01 \mathrm{mg} / \mathrm{dl}, 12$ 주 $44.83 \pm 8.18 \mathrm{mg} / \mathrm{dl}$ 로 $16.4 \%$ (6.33 $\mathrm{mg} / \mathrm{dl}$ ) 증가하는 경향을 보였으나, 통계적으로 유의한 차이 는 나타나지 않았다. DE그룹에서는 0주 $41.50 \pm 8.50 \mathrm{mg} / \mathrm{dl}, 12$ 주 $46.66 \pm 8.47 \mathrm{mg} / \mathrm{dl}$ 로 $12.4 \%(5.16 \mathrm{mg} / \mathrm{dl})$ 증가하는 경향을 보였으나, 통계적으로 유의한 차이는 나타나지 않았다. 유산 소 운동 후 $\mathrm{D}$ 그룹에서는 0 주 $44.50 \pm 5.04 \mathrm{mg} / \mathrm{dl}, 12$ 주 $45.50 \pm 5.20 \mathrm{mg} / \mathrm{dl}$ 로 $2.2 \%(1 \mathrm{mg} / \mathrm{dl})$ 증가하는 경향을 보였으 나, 통계적으로 유의한 차이는 나타나지 않았다. 또한 처치 후 다른 그룹과의 비교에서 가장 낮은 수치를 보였다. E그룹에 서는 0주 $43.83 \pm 7.49 \mathrm{mg} / \mathrm{dl}, 12$ 주 $46.50 \pm 7.23 \mathrm{mg} / \mathrm{dl}$ 로 $6.1 \%$ $(2.67 \mathrm{mg} / \mathrm{dl})$ 증가하는 경향을 보였으나, 통계적으로 유의한

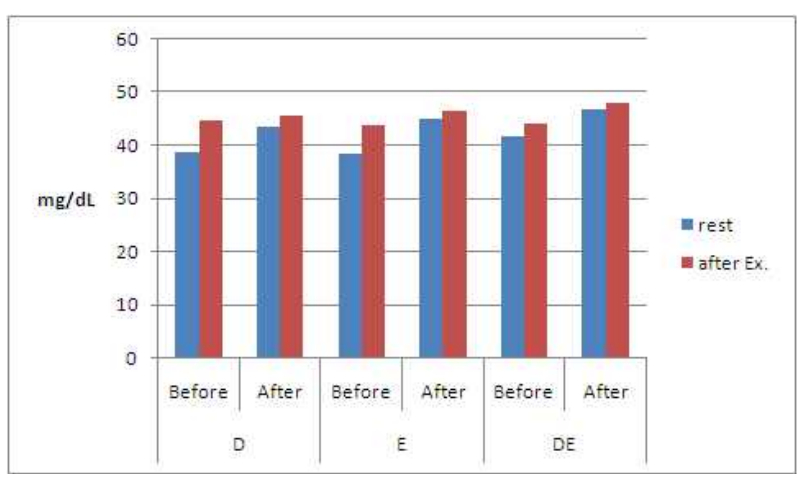

Fig. 6 . The change of plasma HDL concentration after 12 weeks treatment. 
차이는 나타나지 않았다. $\mathrm{DE}$ 그룹에서는 0 주 $44.00 \pm 9.29$ $\mathrm{mg} / \mathrm{dl}, 12$ 주 $48.00 \pm 8.64 \mathrm{mg} / \mathrm{dl}$ 로 $9.1 \%$ (4 mg/dl) 증가하는 경향을 보였으나, 통계적으로 유의한 차이는 나타나지 않았다.

\section{고 찰}

본 연구는 체중과 체지방 감량에 DG섭취가 효과적이라는 영양학적 지식에서 그 효과를 운동과 비교하였으며, DG섭취 와 운동을 병행시켜 그 시너지 효과를 알아 보기 위하여 비만 인을 대상으로 세 가지 실험 조건(diacylglycerol 섭취:DG, 유 산소 트레이닝:E, diacylglycerol 섭취와 유산소 트레이닝:DE) 에 따른 12 주간의 처치가 혈중 지질성분 및 체중 미치는 영향 을 규명하고 기초대사량 변화를 관찰함으로써 임상적 및 대사 적 측면에서 비만 개선 효과를 규명하는데 그 목적을 두고 있다.

본 실험의 결과로 체중은 모든 그룹에서 감소하였고 유산소 트레이닝을 실시한 $\mathrm{E}$ 그룹과 $\mathrm{DE}$ 그룹이 다른 그룹에 비해 더 많이 감소되었다. 체지방률은 모든 그룹에서 감소하였고 유산 소 트레이닝을 실시한 $\mathrm{E}$ 그룹과 $\mathrm{DE}$ 그룹이 다른 그룹에 비해 더 많이 감소되었다. 안정 시 대사량은 $\mathrm{D}$ 그룹에서는 그 변화 가 미미하였지만 유산소 트레이닝을 실시한 그룹에서 유의하 게 증가 하였다. 혈중 지질성분은 모든 그룹에서 $\mathrm{TC}, \mathrm{TG}, \mathrm{LDL}$ 은 감소한 반면, $\mathrm{HDL}$ 은 증가하였다. 즉 결과를 종합해 보면, $\mathrm{DG}$ 섭취가 체지방률 감소에 효과가 있는 것으로 나타났으며, $\mathrm{DG}$ 만 섭취하기 보다 유산소 트레이닝과 병행 했을 때 체중과 체지방률 감소에 더 효과가 있는 것으로 나타났다. 안정 시 대사량의 증가는 DG섭취만으로는 증가하지 않으며 유산소 트레이닝 시 증가하는 것으로 나타났다. 혈중 지질 성분은 모 든 그룹에서 개선됨으로써 DG섭취, 유산소 트레이닝 둘 다 효과적인 것으로 나타났으며, $\mathrm{DG}$ 섭취와 유산소 트레이닝을 병행한 그룹에서 더 큰 개선 효과를 보였다. 이와 같이 DG섭 취는 혈중 지질개선, 비만개선, 체지방율 감소에 영향을 미친 다는 사실을 도출 할 수 있으며 유산소 운동과 병행 했을 때 더욱 더 효과적이라는 사실을 알 수 있었으며 위와 같은 결과 를 바탕으로 논의 하고 자 한다.

현재 비만과 당뇨병, 고혈압, 고지혈증과 같은 비만관련 질 병의 증가와 심폐질환의 위험성 증가는 건강과 관련되어 세계 적인 문제점으로 대두되어왔다[5]. 운동은 비만치료에 있어서 가장 중요한 치료요법으로, 운동의 가장 중요한 역할은 비만 인의 체중 감소 및 현재의 체중을 유지하는 것이다. 운동을 통하여 일상생활이 활동적이 되면 체중이 감소하고 체력 수준 특히 심폐지구력이 향상된다[6]. 만약 체중 감소가 크게 나타 나지 않는다 할지라도, 운동과 훈련을 통하여 심폐지구력이 좋은 수준을 보이는 비만인은 마른 사람 보다 심혈관계 질환 (CVD)발병률의 위험이 감소된다는 것이다[8]. 12 주간 유산소 트레이닝에 따른 신체적 특성의 변화에 미치는 영향을 검증하
기 위하여 실시한 본 연구 결과, RMR이 유의하게 증가한 것으 로 나타났는데 이것은 잠재적으로 큰 중요성을 갖는다. 이러 한 결과는 훈련이 제지방량을 증가시켜 안정 시 대사량을 증 가 시킨다는 요인으로 작용하였다는 선행연구와 일치한다 [11]. 한편 과잉의 지방 섭취는 비만의 주요 유발 원인 중 하나 라고 생각되고 있으며[3], 비만인들의 지방과 기름 섭취는 전 체 섭취 칼로리의 $30 \%$ 를 차지한다[1]. 지방 섭취의 제한과 지 방 대체와 관련된 많은 식이 프로그램에 참가한 비만인들은 감소되었던 체중이 되돌아가고, 정상 범위 내에서 $\mathrm{BMI}$ 를 지속 적으로 또는 유지하는 것이 드물다[4]. 그렇기 때문에 대체 기 름의 개발은 일상생활에서 전통적 요리 기름과 같이 사용할 수 있고, 체중 조절에 유익할 것이라고 기대된다[18]. 이러한 $\mathrm{DG}$ 는 식용유에 자연적으로 소량 함유되어 있고, DG가 풍부 한 기름(>80 wt\% diacylglycerol)은 전통적 요리 기름인 주로 triacylglycerol (TG)로 구성된 기름과 맛, 형태, 물질 특성, 기 능성과 관련된 물리화학적 특성이 유사하다. DG는 1981년 일 본에서 연구가 착수되어 후생성에서 "FOSHU (특수 목적 건 강식품)"으로 승인 되었고,미국 FDA에서 "GRAS (일반적으 로 안전하다고 인정되는 식품)"로 승인되었으며 이에 보다 안 전하고 효과적인 비만개선의 효과를 알아보기 위해서 $\mathrm{DG}$ 의 에너지 대사 기전에 대한 연구가 선행되어야 하며, 카테콜라 민, CAMP, HSL, Insulin등과 같은 지방대사와 관련된 항목들 에 대한 추가적인 분석이 이루어짐으로써, $\mathrm{DG}$ 섭취와 트레이 닝의 비만개선효과를 보다 신뢰성 높게 예측할 수 있으리라 본다.

\section{References}

1. Akoh, C. C. 1995. Lipid-based fat substitutes. Crit. Rev. Food Sci. Nutr. 35, 405-430.

2. American college of Sports Medicine. 2005. ACSM's guidelines for exercise testing and prescription, 7th eds., Lippincott: Williams \& Wilkins. Philadelphia.

3. Bray, G. A. and B. M. Popkin. 1998. Dietary fat intake does affect obesity. Am J. Clin. Nutr. 68, 1157-1173.

4. Fontaine, K. R., D. Yang, G. L. Gadbury, S. Heshka, L. G. Schwartz, R. Murugesan, J. L. Kraker, M. Heo, S. B. Heymsfield, and D. B. Allison. 2003. Results of soy-based meal replacement formula on weight, anthropometry, serum lipids \& blood pressure during a 40-week clinical weight loss trial. Nutr. 18, 2-14.

5. Ford, E. S., W. H. Giles, and W. H. Dietz. 2002. Prevalence of the metabolic syndrome among US adults: findings from the third national health and nutrition examination survey. JAMA 287, 356-359.

6. Jones, D. W., M. E. Miller, M. R. Wofford, D. C. Anderson, M. E. Cameron, D. L. Willoughby, C. T. Adair, and N. S. King. 1999. The effect of weight loss intervention on antihypertensive medication requirements in the hypertension optimal treatment (HOT) study. Am J. Hypertens. 12, 
$1175-1180$

7. Kamphuis, M. M., D. J. Mela, and Westerterp-Plantenga. M. S. 2003. Diacylglycerols affect substrate oxidation and appetite in humans. Am J. Clin. Nutr. 77, 1133-1139.

8. Lee, Y. H., Y. W. Song, H. S. Kim, S. Y. Lee, H. S. Jeong, S. H. Suh, J. K. Park, J. W. Jung, N. S. Kim, C. I. Noh, and Y. M. Hong. 2010. The effects of an exercise program on anthropometric, metabolic, and caediovascular parameters in obese children. Korean Circ. J. 40, 179-184.

9. McArdle, W. D., F. I. Katch, and V. L. Kathc. 2000. Essentials of Exercise Physiology. Lippincott: Williams \& Wilkins.

10. Mauer, J., B. Chaurasia, L. Plum, T. Quast, B. Hampel, M. Bluher, W. Kolanus, C. R. Kahn, and J. C. Bruning. 2010. Myeloid cell-restricted insulin receptor deficiency protects against obesity-induced inflammation and systemic insulin resistance. PLOS Genet 6, e1000938.

11. Melby, C. L., W. D. Schmidt, and D. Corrigan. 1990. Resting metabolic rate in weight-cycling collegiate wrestlers compared with physically active, noncycling control subjects. Am J. Clin. Nutr. 52, 409-414.

12. Nagao, T., H. Watanabe, N. Goto, K. Onizawa, H. Taguchi, N. Matsuo, T. Yasukawa, R. Tsushima, H. Shimasaki, and H. Itakura. 2000. Dietary diacylglycerol suppresses accumulation of body fat compared to triacylglycerol in men in a double-blind controlled trial. J. Nutr. 130, 792-797.

13. Niskanen, L., S. Haffner, L. J. Karhunen, A. K. Turpeinen, H. Miettinen, and M. I. Uusitupa. 1997. Serum leptin in relation to resting energy expenditure and fuel metabolism in obese subjcts. Int J. Obes. Relat. Metab. Disorb. 21, 309-313.
14. Pollock, M. L. and J. H. Wilmore. 1990. Exercise in health and disease. 2nd ed Philadephia. Saunders.

15. Poehlman, E. T., P. J. Arciero, C. L. Melby, and S. F. Badylak. 1988. Resting metabolic rate and postprandial thermogenesis in vefetarians and nonvegetarians. Am J. Cin. nutr. 48, 209-213.

16. Rudkowska, I., C. E. Roynette, I. Demonty, C. A. Vanstone, S. Jew, and P. J. Jones. 2005. Diacylglycerol: efficacy and mechanism of action of an anti-obesity agent. Obes. Res. 13, 1864-1876.

17. Scharhag-Rosenberger, F., T. Meyer, S. Walitzek, and W. Kindermenn. 2010. Effects of one year aerobic endurance training on resting metabolic rate and exercise fat oxidation in previously untrained men and women Int. J. Sports Med Epub. ahead of print.

18. Takase, S., K. Tanaka, K. Suruga, M. Kitagawa, M. Igarashi, and T. Goda. 1998. Dietary fatty acids are possible key determinents of cellular retinol-binding protein II gene expression. Am J. Physiol. 274, 626-632.

19. Teramoto, T., H. Watanabe, K. Ito, Y. Omata, T. Furukawa, K. Shimoda, M. Hoshino, T. Nagao, and S. Naito. 2004. Significant effects of diacylglycerol on body fat and lipid metabolism in patients on hemodialysis. Clin. Nutr. 23, 1122-1126.

20. Webb, P. and S. Sangal. 1991. Sedentary daily expenditure: a base for estimating individual energy requirements. $A m$ J. Clin. nutr. 53, 606-611.

21. Williams, M. H. 1999. Nutrition for Health, Fitness \& Sport, 5th eds., Mc Graw Hill.

\section{초록 : 유산소운동과 diacylglycerol 섭취가 비만인의 혈중 지질성분 및 안정 시 대사량의 변화에 미치는 영향 \\ 이문열 ${ }^{1} \cdot$ 백일영 ${ }^{1}$ · 곽이섭x \\ (동의대학교 체육학과, ${ }^{1}$ 연세대학교 체육학과)}

본 연구는 체지방을 감소시키는데 효과적이라는 diacylglycerol (DG) 섭취와 유산소운동이 체구성비의 변화 및 혈중 지질 개선에 미치는 영향을 규명하고 안정 시 대사량 변화를 관찰함으로써 임상적 및 대사적 측면에서 비만 개선 효과 를 규명하는데 그 목적이 있었다. 본 연구의 대상은 의학적으로 다른 질병을 동반하지 않은 비만 남자 대학생으로서 연구의 의의를 충분히 이해하고 자발적으로 참여 의사를 밝힌 사람으로 선정하였으며, 체지방 측정 후 $25 \%$ 미만인 자와 흡연자는 대상에서 제외하였다. 모든 피험자들은 기본검사와 사전검사가 끝난 후 세가지(D, E, DE) 집단에 6명씩 무선 배정하였다. 첫 번째 실험군(D)은 diacylglycerol 섭취 조건으로 12 주 동안 diacylglycerol을 섭취하였고, 두 번째 실험군 (E)은 12 주 동안 러닝 트레이닝을 실시하였다. 마지막 세번째 실험군 $(\mathrm{DE})$ 은 12 주 동안 diacylglycerol 섭취와 유산소 트레이닝을 실시하였으며, 본 연구결과 모든 그룹에서 12 주 동안의 그룹별 처치가 진행됨에 따라 체지방이 감소하는 경향을 보였다. 안정 시 대사량은 $\mathrm{D}$ 그룹을 제외하고 모든 그룹에서 증가하는 경향을 보였으며 운동과 다이아실글리세 롤 섭취에 따라 콜레스테롤의 감소가 일어났다. 추후 카테콜라민, CAMP, HSL, Insulin 등과 같은 지방대사와 관련된 항목들에 대한 추가적인 분석이 이루어짐으로써, DG섭취와 트레이닝의 비만개선효과를 보다 신뢰성 높게 예측할 수 있으리라 본다. 